\title{
Poblaciones, vecinos y fronteras rioplatenses. Santa Fe a fines del siglo XVIII*
}

\author{
Teresa Suárez y María Laura Tornay \\ Universidad Nacional del Litoral, Argentina
}

El trabajo versa sobre el crecimiento espacial de una pequeña aldea hispanocriolla - Santa Fe de la Vera Cruz-y los reacomodamientos que sus pagos, pueblos de indios, curatos, capillas y fuertes tuvieron en las tres últimas décadas del siglo XVIII. Tales adecuaciones se produjeron tanto por estrategias de la población flotante en búsqueda de asentamiento, como por cambios institucionales -en el marco de reformas borbónicas y debido a la cercanía de las autoridades virreinales - con que los vecinos "hidalgos" protegieron sus intereses. Así se reconoce una política de fronteras que resulta de las negociaciones de los sectores subalternos con las familias de elite en un momento de expansión ganadera y consecuente aumento de la demanda por tierras. Asimismo, las autoridades de la ciudad lucharon por fijar población en su jurisdicción a los fines de marcar su espacio frente a los avances de cabildos vecinos.

PALABRAS ClAVE: Frontera, poblamiento, vecinos, indígenas, itinerantes, cabildo, fuerte, control social.

This paper discusses the territorial growth of a small Hispanic-Creole town: Santa $\mathrm{Fe}$ de la Vera Cruz, as well as the modifications of its estates, Indian towns, parishes, chapels, and forts along during the three last decades of the eighteenth century. Changes took place not only due to strategic migrations of people looking for settlements but also by institutional reform (the Bourbon Reforms, facilitated by the vicinity of viceroyalty officials) that allowed elites to protect their interests. It is thus possible to recognize a frontier policy generated by negociations of subordinate sectors with elite families at a time of cattle raising expansion, and consequently, of a growing demand for land. In addition, city authorities struggled to settle population within us district and thus set their limits in front of neighboring town councils.

KEYwORDS: Border, population, residents, natives, migrants, town council, fort, social control.

\section{Santa Fe de la Vera Cruz}

Fundada en 1573 en el valle aluvional del río Paraná para "abrir puertas a la tierra..." y enlazar la ruta Lima - Asunción del Paraguay, Santa Fe fue trasladada de su original emplazamiento al sitio actual, catorce leguas al SO, ocho décadas después, buscando una mejor conexión en esa ruta

* Agradecimiento: las autoras agradecen a la Dra. Judith Farberman y a la Dra. Raquel Gil Montero por sus desinteresados comentarios a una versión previa de este trabajo, como asimismo a los evaluadores anónimos del Anuario de Estudios Americanos. 
y escapando de la presión indígena del Chaco. La gran extensión espacial que le adjudicó su fundador Juan de Garay (cincuenta leguas a los cuatro vientos) quedó desde un comienzo fuera del control efectivo de las autoridades políticas, ya sea al estar en manos indígenas o ser disputada por jurisdicciones vecinas. A diferencia de otras ciudades coloniales, su poblamiento fue muy dinámico, quedando en el lugar tan sólo una parte de las familias españolas "principales", en tanto que sectores de diversos orígenes y procedencias llegaban y se iban tras efímera permanencia.

Área periférica al virreinato del Perú en los siglos XVI y XVII, desde mediados del XVIII, Santa Fe se vio beneficiada por la reorientación económica y demográfica hacia el Atlántico a raíz de la crisis de los territorios del virreinato peruano, los cambios económicos generales del mundo europeo y la política reformista de los Borbones. La reafirmación del bastión militar platense, la creación del virreinato del Río de la Plata en 1776, la promulgación del libre comercio con el Reglamento de 1778, y la consolidación de un poder político y económico fuerte en el extremo sur del imperio español, permitieron a la región rioplatense con centro en Buenos Aires consolidarse como el polo más dinámico de todo el hinterland, fundamentalmente por su ganadería. ${ }^{1}$

El ascenso del litoral estuvo dado, en gran parte, por su importancia en las rutas que comunicaban ambos océanos. Santa Fe fue durante cuatro décadas (entre 1740 y 1780) "Puerto Preciso" en la navegación del Paraná de los productos del Paraguay, obligados por disposición real a recalar en este puerto y pagar impuestos para continuar en carretas hacia otros destinos, especialmente el norte minero. Por su ubicación, esta ciudad era el paso obligado de los mercaderes que viniendo del Paraguay intentaban llegar a las más importantes plazas comerciales del Tucumán, Salta y Perú, logrando con ello la conexión con una economía con moneda metálica, escasa en Santa Fe. Al ser ciudad de paso permitía a los vecinos mantener relaciones económicas, sociales y políticas con otros centros regionales, al mismo tiempo que sostenía estrechas vinculaciones con el centro emergente, Buenos Aires, lo que la conectaba con la vía atlántica.

La yerba mate de las Misiones primero, y el ganado vacuno y mular de las estancias santafesinas después, se constituyeron en las más importantes fuentes de recursos de la región. Desde finales de la década de 1770,

1 Halperín Donghi, Tulio: Revolución y guerra. Formación de una élite dirigente en la Argentina criolla. Siglo XXI editores, México, 1979, pág. 31. 
MAPA N. ${ }^{\circ}$ 1: SANTA FE EN EL ESPACIO RIOPLATENSE A FINES DEL SIGLO XVIII

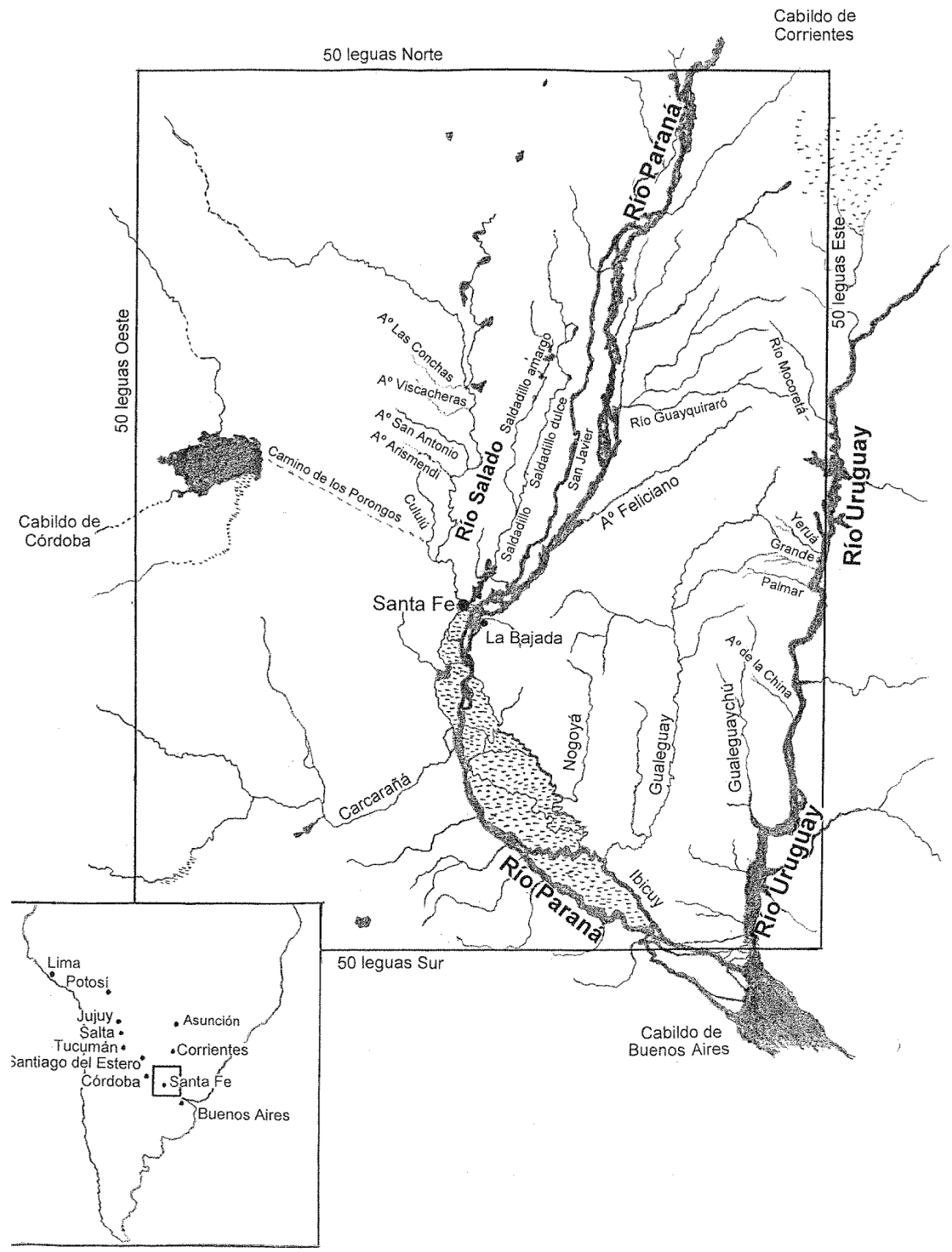

Descripción de su jurisdicción, ríos y cabildos cercanos. Ubicación de la ciudad en la ruta LimaBuenos Aires. 
cuando Santa Fe dejaba de gozar del privilegio de Puerto Preciso, los sectores mercantiles aprovecharon su relativa cercanía del interior y las viejas rutas que con él lo unían, y se enriquecieron con la cría y comercio de mulas que llevaban a vender, en grandes arrias, hasta Salta y Potosí. ${ }^{2}$ Los cueros y sebo vacunos, por otra parte, se dirigían crecientemente hacia Buenos Aires. ${ }^{3}$

En la segunda mitad del siglo XVIII, el espacio santafesino ocupado para la producción ganadera estuvo ligado al corredor fluvial paranaense y se había expandido entre nuevos curatos y pagos donde vecinos hacendados, puesteros y la orden jesuita poseían tierras y ganados de variada extensión. Al Sur de la ciudad, el pago de los Arroyos había crecido desde finales del siglo XVII en torno a la estancia de Domingo Gómez Recio en una tierra fértil e importante en cursos de agua. La tendencia se acentuó a comienzos del XVIII, cuando el avance guaycurú desde el Chaco condujo a un grupo de pobladores a establecerse al sur del río Carcarañá, donde también los jesuitas instalaron su estancia de San Miguel. Las autoridades de Santa Fe dotaron de institucionalidad al pago de los Arroyos nombrándole un alcalde de hermandad en 1725 y constituyéndolo como curato en 1730. También en el Sur y Suroeste - entre Santa Fe y los ArroyosCoronda fue nombrada en 1749 pueblo y curato.

Hacia el Este de Santa Fe, cruzando la Laguna Grande o de Setúbal, y entre los arroyos contribuyentes del Paraná, el pago de Rincón se constituyó en un espacio de sementeras y vaqueos para los vecinos santafesinos. Pero especialmente la Bajada de Entre Ríos en la otra banda del río Paraná, fue el espacio de reproducción y pastoreo natural del ganando vacuno y caballar introducido ya en el siglo XVII por hacendados como Vera Muxica, Crespo y Larramendi. El interés en esta expansión hacia el este del Paraná comenzó a chocar entre 1760 y 1767 con similares intereses de parte de vecinos y jesuitas de Corrientes y Buenos Aires, como lo muestran distintos informes militares y eclesiásticos del siglo XVIII.

Por último, hacia el Norte de la ciudad de Santa Fe se extendieron, después de establecidas las reducciones de indios, una sucesión de estancias en las inmediaciones de los ríos Salado y Saladillo sobre sus dos ban-

2 Tal es el caso de vecinos como Juan Francisco Aldao, Manuel Ignacio Diez de Andino, José Teodoro Larramendi, Francisco Antonio Candioti, José de Vera Muxica, entre otros.

3 Garavaglia, Juan Carlos: "Crecimiento económico y diferenciaciones regionales: el Río de la Plata a fines del siglo XVIII”, Economía, Sociedad y Regiones. Ediciones de la Flor, Buenos Aires, 1987; y Mercado interno y economía colonial. Grijalbo, México, 1983. 
das y sus cañadas, en una región que a fines de Siglo constituía económica, política y culturalmente una frontera. ${ }^{4}$

La clave más importante del poblamiento santafesino-entrerriano está en la existencia de caudalosos sistemas fluviales. Efectivamente, tanto las estancias, como los pueblos, postas, fuertes y otras formas de establecimiento humano están localizadas siguiendo los cursos de los ríos, especialmente en sus rinconadas que favorecen el rodeo de ganado cimarrón. Las autoridades coloniales, siguiendo las normativas del derecho indiano, adjudicaron suertes de estancias de una legua frente a un curso de agua. Fueron las ambiciones de los grandes hacendados las que, desatendiendo este criterio acapararon en su beneficio más leguas que las que efectivamente podían poblar. ${ }^{5}$

La otra clave del poblamiento es la vegetación. El bosque es la forma más común, con especies como el ñandubay, tala, palmeras yatay y caranday, algarrobos y quebrachos. La riqueza natural y el clima benigno facilitaron el sustento a los indios Charrúas, con base proveniente de cacería — ciervo y carpincho- o de ganado cimarrón. ${ }^{6} \mathrm{Al}$ oeste del Paraná, los pastos son la formación más corriente, en tanto al norte del Salado, predominan el bosque y el monte bajo de espinillos.

\section{Estrategias de poblamiento y política de fronteras}

Este trabajo demuestra los intentos de consolidación de un grupo de vecinos de Santa Fe en el último cuarto del siglo XVIII definiendo territorialmente sus propiedades, fijando normativas sobre pobladores de azarosa permanencia, institucionalizando la jurisdicción de la ciudad (fronteras E y N) y procurando una reafirmación espacial ante cabildos cercanos. Las contingencias del poblamiento — migraciones y formación de pagos,

4 Cervera, Manuel: Historia de la ciudad y provincia de Santa Fe, 1573-1853. Imprenta "La Unión", Santa Fe, 1907. Cap.10 y 11. Pérez Colman, César: Apuntes Históricos: El Nord este de Entre Ríos. Fundación de Concordia. Talleres de la Acción, Paraná, 1933; y Pérez Colman, César: Historia de Entre Ríos, 1520-1810. Imprenta de la Provincia, Paraná, 1936.

5 En la margen derecha del Paraná vuelcan sus aguas los ríos Salado, Saladillo, Carcarañá, Coronda, Las Conchas, Vizcacheras, Arismendi y Cululú, entre otros. Por la margen izquierda, desembocan en el Paraná una red más nutrida aún, formada por los cursos del Guayquiraró, Feliciano, Alcaraz, Hernandarias, Las Conchas, Nogoyá, entre los más grandes. Sobre el río Uruguay, límite Este de la jurisdicción de Santa Fe, desembocan el Mocoretá, Mandisoví, Ayuí, Yeruá, Palmar y otros.

6 Serrano, Antonio: Los primitivos habitantes de Entre Ríos. Ministerio de Educación de Entre Ríos, Paraná, 1950; y Pérez Colman, C.: Historia de Entre Ríos. 
reducciones, fuertes - resultan de la coyuntura colonial en el marco ofrecido por la gestión borbónica. La propuesta de estudio surge habiéndose revisado las valoraciones efectuadas por la historiografía sobre el tema y de la interpretación crítica de las fuentes capitulares. Se replantean las relaciones entre hispanocriollos e indígenas, las políticas del cabildo y la lógica de resistencia a la coacción colonial por parte de los sujetos subalternos.

La lectura de documentación institucional de distinta procedencia para el último cuarto del siglo XVIII evidencia un proceso de desequilibrios y reacomodos en la jurisdicción litoral y especialmente en Santa Fe. A la parcial dispersión de las reducciones jesuitas de San Javier, San Jerónimo y San Pedro luego de la expulsión de la Orden de San Ignacio se agregó la llegada de pobladores principalmente de Santiago del Estero, Corrientes, Córdoba y Tucumán conformando una población heterogénea, en algunos casos errante, sin control o en tránsito, y en otros casos asentada en los pagos de la campaña y en la ciudad.

Desde el punto de vista del vecino de la ciudad, la frontera era el lugar lejano y vacío de sociedad cristiana. Parcialmente estaba identificada como tierra de indios, con un espacio que éstos ocupaban si querían, se desplazaban en él, sentaban su dominio. Pero también la frontera era un lugar adonde había forasteros, quienes llegaban solos, en grupos, o en familias desde las provincias del interior. En este sentido, los vecinos santafesinos elaboraron una apreciación sobre dos competidores diferentes ocupantes de su espacio: los indígenas de las ex reducciones y los llegados de otras provincias. Por otro lado, las pretensiones de los cabildos de Córdoba, Buenos Aires y Corrientes sobre el control de recursos naturales y humanos que los vecinos de Santa Fe reclamaban para sí, parecen haber sido un tercer competidor y elemento de peso en las decisiones sobre las áreas de frontera.

La política de fronteras de la segunda mitad del siglo XVIII en Santa Fe, tomó un curso diferente de la llevada a cabo en tiempos tempranos. Fueron los sujetos subalternos itinerantes o establecidos los que obligaron

7 Las fuentes que nos remiten a este momento evidencian una gran tensión entre las que provienen de los Borbones, innovadoras y demandantes de cambios en la gestión local, y por otro lado las emanadas del Cabildo, que resisten los controles virreinales y propugnan continuar las prácticas tradicionales de funcionamiento. De este modo, el discurso de actas y expedientes presenta el sesgo resultante de la ocasional fricción entre niveles de autoridades, peninsulares y locales, expresión de una variedad de poderes e intereses.

$8 \mathrm{Si}$ bien se evidencia el progresivo abandono de las tres misiones mencionadas, afirmamos - a diferencia de la historiografía sobre el tema- que el sector mayoritario de sus pobladores permaneció en su emplazamiento por lo menos hasta fines del siglo XVIII. Las matrículas de los pueblos de indios superan el número de dos mil en 1785, y parecidas cifras menciona D. Félix de Azara para 1797. 
a las élites gobernantes a redefinir dichas políticas: "pidiendo reducción..." como estrategia (guaycurú) para acceder al ganado desde la década de 1740; solicitando en éstas un funcionamiento económico prescindente de las autoridades (curas y administradores); o abandonando las reducciones - algunos de sus pobladores - para establecerse como agregados, conchavados o productores independientes, desde la década de 1780. Sumándose a éstos, los grupos o familias que llegaban desde Corrientes, Tucumán, Santiago del Estero o Córdoba, constituían núcleos poblados o asentamientos en las tierras que los vecinos de la ciudad reconocían como propias. Los pedidos de formación de parroquias por parte de nuevos pobladores en áreas de colonización reciente en "los entre ríos" confrontaban con el interés de unos pocos grandes hacendados por acaparar tierras para formar estancias.

En respuesta a los problemas anteriores y para atender las áreas sin control español, el cabildo tuvo que hacer ajustes institucionales: efectuar traslados compulsivos de población, designar jueces, reforzar las milicias, repoblar reducciones y fuertes, fundar otros nuevos y constituir pueblos y parroquias.

Es decir, la presencia de estos nuevos pobladores no parece haber generado una sola reacción. La guerra, los pactos, los conciertos, los traslados a los fuertes fueron estrategias que se dieron alternativamente. Sobre mediados del XVIII Santa Fe instrumentó la fundación de reducciones primero y de fuertes después radicando en ellos población aborigen no belicosa.

\section{Los indígenas de las ex reducciones jesuíticas}

Las reducciones San Francisco Xavier, San Jerónimo del Rey y San Pedro se poblaron con familias indígenas del denominado Chaco austral ${ }^{9}$ - localizado al sur del Río Bermejo - pertenecientes al grupo Guaycurú. La lengua del mismo nombre era hablada por los pueblos Abipón, Mocoví, Toba, Pilagá y Guaycurú-Mbaya principalmente, que habitaban las llanuras subtropicales en la transición de las formaciones estepa y selva. De los tres núcleos étnicos reconocidos en la región chaqueña, dos de ellos, tobas 1947.

9 Serrano, Antonio: Los aborígenes argentinos. Síntesis etnográfica. Nova, Buenos Aires, 
y afines o guaycurús, y matacos o chaqueños típicos, poseen un sustrato cultural común. Se trataba de un conjunto de tribus pedestres, no agrícolas, que hablaban una misma lengua con formas dialectales diferentes. Por otro lado, estarían diferenciados en su base económica dos grupos: los chiriguano-chané, cultivadores amazónicos (los primeros de origen guaraní y los segundos, araucanos), y las tribus de cazadores recolectores. Los testimonios escritos del siglo XVIII reconocen tres grupos diferenciados por ambientes ecológicos: los Riikaes, que vivían en campo abierto, los Nakaigetergehe, que lo hacían en las selvas, y los Yaaukanigas, en la región del agua.

Aunque genéricamente son abipones, los diferentes grupos constituyeron las poblaciones misionales de San Jerónimo (fundada en Santa Fe, en 1748, con Abipones Riikaes), Concepción (fundada en Santiago del Estero, trasladada varias veces entre 1749 y 1753, y poblada por indios Nakaigetergehe), San Fernando (fundada en Resistencia, 1750, poblada por Yaaukanigas) y del Rosario (fundada en Formosa, 1763). Estas misiones intentaron poner fin a las correrías de indios belicosos y nómadas en el límite sur del Chaco austral.

En el espacio controlado por Santa Fe, los pueblos de San Javier, San Jerónimo y San Pedro fueron establecidos entre 1743 y 1765 cuando abipones y mocovíes pidieron reducción tras las epidemias de viruela y la escasez de recursos con qué sustentarse. ${ }^{10}$

Las tres reducciones se instalaron al Norte y NE de la ciudad de Santa Fe. La más cercana, San Pedro, se situaba a veintiún leguas, cerca del río Saladillo amargo; San Javier fue levantada finalmente, luego de dos traslados en esa dirección, a unas treinta y un leguas sobre su mismo río; y San Jerónimo - por exigencia de los mismos abipones - terminó estableciéndose setenta leguas al Norte de la ciudad, a pocas leguas del río Paraná. ${ }^{11}$ El establecimiento de ésta última puede dar cuenta de las estrategias de poblamiento y aprovechamiento de recursos de los indígenas, y su capacidad para "negociar" con el grupo de vecinos de Santa Fe. La localización de la primera reducción de San Jerónimo, fundada para los abipones Riikahes en un lugar cercano a Santa Fe y próximo al Salado, fue rechazada. Ellos pidieron que el lugar del nuevo pueblo fuera el arroyo

10 San Javier (mocoví) 1743, San Jerónimo del Rey (abipones) 1748 y San Pedro (mocoví) 1765.

11 Calvo, Luis María: La Compañía de Jesús en Santa Fe, Ediciones culturales santafesinas, Santa Fe, 1993, 3. ${ }^{a}$ parte, págs. 102-113. 
denominado Del Rey, "Ychimaye" o "de las calabaza", a setenta leguas de Santa Fe. El espacio disponía, además de lugar de pastoreo para los animales, selvas de árboles muy útiles para el fuego y los enseres y animales de caza, lagunas de agua dulce con peces, cocodrilos, tortugas y lobos de agua. Asimismo, disponía de elementos de defensa frente a los españoles, que tendrían difícil acceso tanto a pie como a caballo para transitar las dos leguas que los distanciaba del río Paraná. ${ }^{12}$

El proceso de interacción que se dio entre los tres pueblos y la villa santafesina es bastante complejo. Los jesuitas subsidiaron parcialmente los pueblos hasta su expulsión, ya que las actividades agrícolo-ganaderas y manufactureras no lograban sustentar adecuadamente a la población. ${ }^{13}$ Los administradores posteriores trataron de sacar partido poniendo trabas al comercio que los indígenas tenían con diversos mercaderes. Los vecinos de la ciudad de Santa Fe tenían simpatizantes para cada una de las dos naciones indígenas: Melchor de Echagüe y Andía tuvo una política promocoví cuando entre 1776 y 1792 ofició como teniente de gobernador. Asimismo, José Tarragona, administrador de los pueblos guaycurúes y también simpatizante de los mocovíes, alarmaba a las autoridades denunciando que los ataques abipones a la misión de San Pedro ponían en peligro su existencia. ${ }^{14}$

Los caciques eran conocedores de estas preferencias y de los intereses a las que respondían. El cacique abipón de San Jerónimo, Miguel Benavídez —en razón de negarse a estar tutelado por los españoles - fue a denunciar ante el Virrey Vértiz que Tarragona controlaba el comercio de los indios censurándoles la entrada de otros mercaderes:

"somos capaces por nosotros mismos de comerciar; no por la ayuda de un administrador y protector. Siendo libres nuestras personas y bienes, no tenemos una condición inferior que los españoles....". ${ }^{15}$

12 Suárez, Teresa: "Gentiles y Reducidos. Modelos y conceptos usados en textos de fines del Siglo XVIII para categorizar las unidades familiares de indígenas chaqueños”, IX Jornadas Interescuelas / Departamentos de Historia, Córdoba, 24 al 26 de septiembre de 2003.

13 La participación de la orden de San Ignacio y la planificación de las plantas de las reducciones pueden verse en Calvo, Luis María: La compañía de Jesús en Santa Fe, Ediciones culturales santafesinas, 1993.

14 Saeger, James: "Another View of the Mision as a Frontier Institution: The Guaycuruan Reduction of Santa Fe, 1743-1810”, HAHR, Duke University Press. Muestra, sin embargo, en cifras año a año que el número de pobladores en las tres reducciones, si bien oscilante, fue bastante numeroso hasta fines del siglo XVIII.

15 James Saeger cita esta relación al Virrey, en "Another View... 
En consecuencia, Benavídez pedía que a los mercaderes que quisieran comerciar con ellos se les permitiera entrar a los pueblos sin restricciones. Además denunció a Tarragona por llevarse treinta mil cabezas de ganado "a cambio de yerba podrida y unos cuchillos mal hechos" y de favorecer que los mocovíes trabajaran en sus estancias. Por su parte, el defensor de los abipones era el padre mercedario Blas Brite, quien con una actitud paternalista defendía a los cazadores abipones reducidos ya que, en esta condición, habían perdido sus montes.

Las tres misiones propiciaron la mezcla étnica y la aculturación de los pueblos guaycurúes, aunque nunca aceptaron totalmente la sociedad hispana. Las autoridades consideraban que estos pueblos constituían un antemuro de los chaqueños, por eso los vecinos contribuían con ganado a su manutención. En 1786 los abipones de San Jerónimo pidieron ayuda contra los tobas y mocovíes del Chaco. El sentido que alguna historiografía daba a estas peleas interétnicas, en que libres y reducidos de una misma nación se apoyaban para guerrear contra otra, era su enemistad. Sin embargo, más recientemente se le atribuye a aquellas luchas una intención cultural de establecer la preeminencia sobre los vencidos: el que ganaba quedaba con status reconocido. Así, las peleas no eran de aniquilamiento sino "bravuconadas". ${ }^{16}$ Aunque no se dispone de una cronología de dichas luchas interétnicas, los jesuitas Paucke y Dobrizhoffer en sus respectivas obras reiteran estas rivalidades.

$\mathrm{Al}$ cabo de casi tres décadas en reducción, la conversión de los abipones fue sólo relativa, ya que se mantenían infieles en su mayoría casándose con dos o más mujeres, pintando a sus hijos, observando costumbres de su gentilidad sin vivir en sujeción a las pautas cristianas. ${ }^{17}$ De todos modos, se adaptaron rápidamente. Benavídez, de nombre indígena Ychoalay, fue estanciero, aprendió el español y viajó a otras provincias. Los Abipones de San Jerónimo dejaron el pueblo en 1803, pero no para volver al Chaco sino para trabajar en estancias o en la milicia. Por eso la reubicación se pudo hacer en los fuertes: estos indios eran confiables para la autoridad española en tanto que aculturados y pacíficos. Y además necesarios, porque conocían las formas de ataque de las otras parcialidades chaqueñas no sometidas. Así, aunque el adoctrinamiento fracasara, el desarrollo poblacional de Santa Fe fue favorecido.

16 Según Saeger, "a show of bravado sufficed".

17 Archivo General de la Provincia de Santa Fe (en adelante AGPSF), Actas de Cabildo (en adelante AC), 17 de octubre de 1774, T. XIV, fs. 341-343 v. 
Estos indios, integrados al espacio español en la medida en que permanecieran en sus reducciones y en los lugares asignados a ellos, pasaban a ser sujetos indeseables cuando abandonaban sus pueblos y se dispersaban por el campo en compañía de otros. De allí que las autoridades tratasen de reubicarlos nuevamente en el área reducida. La intervención de los sacerdotes fue funcional a este objetivo. Seguramente hay exageración en los textos, sin embargo son indicadores del movimiento de desgranamiento poblacional de los pueblos de indios. Un oficio del cura de San Jerónimo describe en 1789 la situación de dispersión de una parte de los pueblos:

“...sólo se hallan en aquél pueblo muy pocas familias, pues todas las más se hallan dispersas en varias chacras y tolderías de algunos caciques y alcaldes que se mantienen abrigados los unos a los otros en sus labranzas ....". ${ }^{18}$

“... en aquel pueblo sólo se hallan cuatro familias que compondrán hasta el número de treinta personas, las más chinas viejas, que distante de aquel pueblo hacia esta parte como cosa de veinte leguas se hallan en los campos las más de las familias dispersas viviendo en los montes y en las chacras que al efecto han hecho; que para la ciudad de Corrientes se han pasado tres familias...y que las demás se mantienen por distintos parajes de la campaña...". ${ }^{19}$

Por su parte, los curas del pueblo de San Javier fray Julián Obelar y fray José Córdoba plantean la preocupación por la dispersión de los indios:

“...se hallan en términos de desamparar aquel pueblo por no tener cómo mantenerse ellos ni sus naturales... pidiendo que por este Cabildo se les franquee algún socorro de ganado de la estancia de San Antonio del que se halla alzado...". ${ }^{20}$

La política fiscal de los Borbones había ordenado censar a los pueblos de indios a los fines de recaudar tributos. ${ }^{21}$ En 1785 fueron levantados sendos padrones que evidenciaron 2314 personas. ${ }^{22} \mathrm{Si}$ a partir de entonces se demandó tributar, es explicable que las familias indígenas se dispersaran para instalarse de modo autónomo. Luego de la expulsión de los jesuitas, los indígenas del Norte santafesino constituyeron agrupamientos heterogéneos: los que quedaron en los pueblos, los que se incluyeron como trabaja-

18 AGPSF, AC, $1^{\circ}$ de agosto de 1789, T. XV, fs. 393-397.

19 Ibídem.

20 AGPSF, AC, Varios Documentos, 26 de noviembre de 1791, fs. 62-64.

21 Punta, Ana Inés: Córdoba Borbónica. Persistencias coloniales en tiempo de reformas (1750-1800). Talleres Gráficos de la Univ. Nacional de Córdoba, 1997, 2. a parte, 5, págs. 162 a 173 y Apéndice: Documentos VIII y IX, págs. 277 a 281.

22 AGPSF, Archivo de Gobierno I- fojas 86 y subsiguientes. 
dores en las estancias, y los que optaron por una vida independiente. Es muy posible, de todos modos, que pese a esta disgregación mantuvieran relaciones familiares y comunitarias de protección y abastecimiento.

Hemos tratado de evidenciar la complejidad de las políticas que los vecinos santafesinos intentaron en instancias de resolver la problemática indígena, en lugar de la visión más simplificadora de guerra permanente entre españoles e indios. ${ }^{23}$

\section{Los llegados de otras provincias}

A la ocupación de las tierras santafesinas por parte de las familias indias de las otrora reducciones jesuíticas, se agregaron los efectos de un proceso inmigratorio desde las "provincias de arriba": Tucumán, Córdoba, Santiago del Estero y Corrientes. Entre 1776 y el fin del siglo, las autoridades del cabildo, el teniente de gobernador, los curas, obispos y los funcionarios borbónicos incluido el ahora cercano virrey, debieron resolver el ordenamiento de los nuevos núcleos poblados.

A juzgar por lo mencionado en las actas de cabildo, hombres de orígenes geográficos diferentes y sin condición étnica precisada, se trasladaban, asentaban o agregaban libremente a las estancias, donde hacían uso del ganado para su sustento y/o venta, a la vez que entraban en contacto con otros individuos con quienes podían compartir tiempos de ocio y toda una serie de actividades ajenas al control de hacendados y autoridades. Las continuas quejas de los hacendados de la otra banda del Paraná, Coronda, la otra banda del Salado y los Arroyos sugieren que se trata de una crecida población rural sin sujeción, que les preocupa y lleva a tomar enérgicas medidas a juzgar por la insistencia de las denuncias. La identificación y detención de los sujetos que no dieran cuenta de razones legítimas de ocupación aparece frondosamente en documentos del cabildo en este período. Por ejemplo, en una visita de cárcel

“...se hallaron presos Juan Luna, José Bernardo Maldonado, Toribio Basualdo y Dionisio Monserrate, santiagueños, cogidos y remitidos por el cabo de la guardia del Cululú a causa de haberlos hallado en paraje sospechoso y preguntados por su desti-

23 Una tradición historiográfica santafesina enfatizó la guerra blanco-indio, subestimando la realización de otras políticas alternativas. Ver Aleman, Bernardo E.: Santa Fe y sus aborígenes, Junta Provincial de Estudios Históricos, Santa Fe, 1994. 
no respondieron que iban a la casa del Sargento Mayor de Coronda, y al día siguiente hallados por el mismo en otro paraje respondieron que iban a Córdoba..... ${ }^{24}$

Las denuncias se repiten por más de una década y hacen referencia a tres lugares específicos: Tucumán, Córdoba y Santiago del Estero. Los recién llegados ya no son hombres solitarios sino familias del Interior que redefinen el espacio ocupado y generan reacciones entre el grupo de vecinos-hacendados afectados. La documentación repite:

"un número crecido de familias que se han trasladado de las ciudades interiores de las provincias del Tucumán y Córdoba y establecídose furtivamente en esta jurisdicción...". ${ }^{25}$

"varias quejas de que en los Chañares del otro lado del Río Salado se hallan pobladas varias familias cordobesas y santiagueñas que han sido expulsadas de su territorios por vagas y perniciosas, las cuales sin competente licencia se han poblado en dicho paraje con notorio perjuicio de todos los vecinos hacendados...". ${ }^{26}$

"se hallan poblados en las campañas de esta ciudad muchos vecinos así de ésta como de Córdoba y Santiago sin tener éstos cómo poderse mantener con sus familias, ni menos tierras propias...". ${ }^{27}$

"gran tránsito de gentes de todos los sexos por este camino, y que de ésto resultan infinitas extracciones de toda clase de efectos y especies de animales y principalmente de las mulas...". ${ }^{28}$

Otros trabajos de historia regional hablan de un importante movimiento de población a lo largo del siglo XVIII cuyo polo de atracción lo constituyen las zonas rurales del litoral en ascenso. Los padrones de Buenos Aires de 1726, 1744 y 1815, confirman la existencia de población proveniente del interior (tempranamente con los dos primeros censos), que ha llegado a la campaña porteña en sucesivas oleadas migratorias haciendo escala en puntos como Santa Fe y que a través de estrategias individuales o grupales y de las posibilidades ofrecidas por la región en que se asienta, ocupa el espacio con distinto grado de estabilidad. Cordobeses y santiagueños constituyen entre el 80 y el $90 \%$ de los migrantes asentados en los registros bonaerenses. ${ }^{29}$ Para el período que cubre el padrón de 1815, la

24 AGPSF, AC, 11 de abril de 1778, T. XIV fs. 495-497.

25 AGPSF, AC, 13 de noviembre de 1786, T. XV, f. 198.

26 AGPSF, AC, 22 de febrero de 1790, T. XVI, fs. 27-34.

27 AGPSF, AC, 24 de diciembre de 1793, T. XVI, fs. 241-243.

28 AGPSF, AC, 8 de enero de 1798, T. XVI, fs. 466-468.

29 Farberman, Judith: "De las 'provincias de arriba'. Labradores y jornaleros del interior en la campaña porteña 1726-1815”. XVI Jornadas de Historia Económica, Universidad de Quilmes, Buenos Aires, 1998. 
mayoría de esos santiagueños llegados a la campaña bonaerense son casados con mujeres del lugar o conocidas en escalas del itinerario migratorio. ${ }^{30}$

Los pueblos de indios de Santiago fueron proveedores constantes de esta población migrante. ${ }^{31}$ Según el padrón de 1807, casi el 50\% de esa población había emigrado. A diferencia de la "saca de indios" o movimientos de población forzados, propia de los siglos XVI y XVII, hacia fines del XVIII las migraciones fueron ya movimientos voluntarios. Esos movimientos se hicieron tanto bajo la forma de migraciones familiares - preservando formas de trabajo cooperativo extendido en la unidad familiar indígena - como bajo la forma de migrantes individuales que abandonaban temporalmente la unidad doméstica para insertarse en circuitos comerciales externos a sus pueblos. ${ }^{32}$

Córdoba es otro lugar de origen de migraciones. Aquí se detecta la existencia de una población con movilidad espacial, compuesta en gran medida por pequeños productores nucleados en familias crecidas y fuertemente mestizados. Las migraciones se daban en el interior y fuera de la jurisdicción. ${ }^{33}$ Los móviles, a diferencia del caso anterior, estarían vinculados a las fluctuaciones del mercado ganadero.

El otro lugar de donde proviene la población de la que dan cuenta los documentos capitulares es el Tucumán. Sin embargo, en la bibliografía encontramos versiones diferentes. En un trabajo se afirma que en la jurisdicción del Tucumán hay un crecimiento secular sostenido entre 17701870, producto de un florecimiento económico que se manifiesta no sólo en un aumento demográfico natural, sino también en la inmigración regional hacia la ciudad de Tucumán. Por lo tanto no se advierte la emigración de tucumanos hacia otras regiones del Río de la Plata como dato importan-

30 José Mateo encuentra que muchos de los santiagueños que llegan al pago de Lobos en el norte de Buenos Aires a principios del siglo XIX están casados con mujeres santafesinas y tienen hijos nacidos en Pilar, siguiente escala hacia el SE, mostrando un itinerario migratorio completo que involucra a individuos y familias de Santiago del Estero, Santa Fe, Pilar y Lobos que siguen la línea del litoral fluvial. Farberman cita el trabajo del autor: "Población y producción en un ecosistema agrario de la frontera del Salado (1815-1869)", en A. Reguera y R. Mandrini: Huellas en la tierra, Universidad de Tandil, IEHS, 1993.

31 Judith Farberman en otros trabajos profundiza sobre las condiciones de los pueblos de indios: "Los que se van y los que se quedan: familia y migraciones en Santiago del Estero a fines del período colonial": Quinto Sol, Revista de Historia Regional, I, Santa Rosa, 1997; "Migrantes y soldados. Los pueblos de indios de Santiago del Estero en 1786 y 1813" en Cuadernos del Instituto Ravignani, N. ${ }^{\circ}$, Buenos Aires, 1992.

32 Sin embargo, la condición de su permanencia — definitiva o temporaria — en Santa Fe no está registrada en la documentación consultada.

33 Punta, Ana Inés: Córdoba Borbónica, pág. 215. 
te a fines del siglo XVIII. ${ }^{34}$ En otro trabajo, en cambio, se observa la existencia de migraciones en busca de mejores oportunidades hacia el sur de Córdoba, Santa Fe y norte de Buenos Aires, debido a huídas por situaciones compulsivas. ${ }^{35}$

La presencia numerosa de estos sujetos - móviles o en proceso de asentamiento - aparece manifiesta en fuentes cualitativas: actas de cabildo, notas de hacendados, cartas de curas corregidores, informes de expediciones militares, visitas de obispos, comentarios de viajeros, etc. No se dispone en Santa Fe del censo de población que ordenaron los monarcas Borbones en la segunda mitad del siglo XVIII para las ciudades de América, lo que nos deja sin una fuente cuantitativa de gran importancia. De todas maneras, en reiteradas ocasiones se mandaron hacer listas de pobladores ${ }^{36}$, averiguaciones varias ${ }^{37}$, recuentos de vecinos aptos para servir en los oficios anuales ${ }^{38}$, empadronamientos de vecinos de la ciudad con criterios y fines diversos ${ }^{39}$ e indagatorias por conflic-

34 López de Albornoz, Cristina: "Población y fuerza de trabajo en el Tucumán colonial. Un enfoque desde la Historia rural”, en Población y Sociedad, N. ${ }^{\text {5 }}$, Tucumán, octubre 1998, págs. 209-238.

35 Ana María Lorandi se refiere a la emigración a propósito de observar los fenómenos de multietnicidad y multiculturalidad generados por diversos factores, en "Constitución de un nuevo perfil social del Tucumán en el Siglo XVIII”, Boletín del Instituto Ravignani, Tercera Serie, N. ${ }^{2}$ 21, Buenos Aires, 2000, pág. 113.

36 En 1791 se ordena a los comisionados rurales que tomen una relación o noticia de los vecinos que tengan en sus partidos "y que todos aquellos que se reconozcan por vagos, sin haciendas ni fincas propias, les hagan saber que dentro de cuatro días salgan de aquellos territorios...". AGPSF, Varios Documentos, 5 de febrero de 1791, fs. 10v-12v. En 1793 mandan al alguacil mayor que con la tropa necesaria “...pase a la jurisdicción de esta ciudad, de ésta y otra banda del Salado, y haciendo particular averiguación, de los que no conozca los expulse a los fuertes...". AGPSF, AC, 24 de diciembre de 1793, T. XVI, fs. 241v-243.

37 Antes de proceder a la expulsión de familias asentadas en tierras de la otra banda del río Salado, el cabildo comisionó en 1786 al capitán Francisco Solano Frutos "para que tome razón de las familias establecidas en dichos parajes, dé cuenta a este cabildo de las haciendas y labor que tengan para su subsistencia, para en su vista proveer lo que fuere más arreglado en justicia con conocimiento de causa, y todo con el tiempo de ocho días para la expresada comisión..." AGPSF, AC, 21 de agosto de 1786, T. XV, fs. 191-192.

38 El que hizo el alcalde 1. Juan Antonio de la Elguera en 1780 por mandato del virrey consideraba a 45 vecinos de la ciudad y 4 de la campaña aptos para ser alcaldes $1 .^{\circ}, 2 .^{\circ}$ y procurador; a 50 vecinos de la campaña para alcaldes de hermandad, y a 25 vecinos de la ciudad para el cargo de mayordomo de la misma. AGPSF, AC, 7 de febrero de 1780, T. XV, fs. 8-9.

39 Como el realizado en 1781 por el cabildo y el proto médico de la ciudad según la condición económica para determinar el monto que cada familia debe pagar por atención médica: los de $1^{\text {a }}$ dos pesos anuales, los de $2^{\mathrm{a}}$ un peso, y los de $3^{\mathrm{a}} \mathrm{y}$ religiosos mendicantes una limosna. AGPSF, AC, 14 de mayo de 1781, T. XV, fs. 58-59v. Se manda repetir el listado en 1790 para el mismo fin. AGPSF, AC, 4 de noviembre de 1790, T. XVI, fs. 94-98. Con motivo de la "contribución patriótica" exigida por Buenos Aires en 1808 tras la invasión francesa en España, se manda a los alcaldes de hermandad y jueces pedáneos formar un padrón de las poblaciones de Paraná, Coronda y los Arroyos "con especificación de sus casas, corrales y haciendas de marcas propias" AGPSF, AC, 4 de noviembre de 1808, T. XVII, fs. 416v-420v. 
tos ${ }^{40}$. Aunque estos listados no se conserven, las órdenes de hacerlos demuestran una crecida intención de controlar a la población para tomar medidas de distinto orden. Otros documentos informan al pasar algunos datos de población: en una carta al rey, el capellán de Rincón D. Juan Antonio Guzmán dice que allí "hay más de trescientas personas" en $1787 .{ }^{41}$

Los datos cuantitativos de la población de la jurisdicción de Santa Fe nos llegan de Felix de Azara, científico y militar con grado de brigadier enviado por la corona para la demarcación de los territorios limítrofes entre España y Portugal. En su viaje por el Río de la Plata a fines del siglo XVIII lista 87 localidades. A los efectos de este trabajo, en el Apéndice seleccionamos las localidades relevantes. ${ }^{42}$

Para la Bajada de Paraná y los pagos entrerrianos se dispone de un mayor relevamiento de datos de población producidos por autoridades eclesiásticas y militares mandadas desde Buenos Aires, en tanto área de ocupación disputada entre los vecinos de ésta, los de Santa Fe y los de Corrientes. En ellas se da cuenta de una acelerada radicación de familias en los campos. ${ }^{43}$ Los censos de 1803 y 1805 reproducen el proceso y modalidad de ocupación del espacio al estar estructurados por ríos y arroyos: van listando las familias que tienen puestos o estancias sobre sus márgenes, como lo muestra gráficamente el mapa de las estancias del río Salado en Santa Fe. El poblamiento rural se hacía a lo largo de una fuente de agua para el ganado.

40 Entre agosto y octubre de 1809, tras la denuncia de los vecinos de la Bajada de Paraná contra el alcalde de hermandad nombrado desde Santa Fe, el cabildo mandó a inspeccionar "los sujetos firmantes, calidades, clase, vecindario y situación, tomando declaraciones a los vecinos condecorados". AGPSF, AC, 9 de octubre de 1809, T. XVII, fs. 497-499.

41 AGPSF, Reales Cédulas y Provisiones, 19 de noviembre de 1787, T.IV, f. 173.

42 De Azara, Félix: Descripción e Historia del Paraguay y del Río de la Plata. Madrid, 1847. Cuadro titulado "Poblaciones del Gobierno de BsAs", T. I, págs. 344-346. Citamos sólo las pertenecientes a la jurisdicción santafesina (Azara no lista la ex reducción de San Pedro). Se desconoce con exactitud el año en que Azara lo realizó; la publicación del libro fue hecha por su sobrino en 1847. Cuando Gabriel Carrasco levantó el primer censo de Santa Fe, en 1887, citó como antecedentes el Censo de Azara como de 1797.

43 Informe del sargento mayor D. Juan Broin de Osuna, alcalde de hermandad de Paraná desde 1765 a 1769 y jefe de las milicias de dicho partido en 1771 (1771); informe del obispo Malvar y Pinto enviado por el rey para el reconocimiento de los pueblos y recursos de la región mesopotámica en disputa con Portugal (1780); informe de D. Tomás de Rocamora capitán de Dragones sobre la jurisdicción de pueblos entrerrianos (1782); censos parroquiales de Paraná y Gualeguay (1803) y de Alcaráz (1805). 


\section{Las tierras del Salado y las tierras de la Bajada}

Conforme se desarrolló la lucha interétnica entre la ciudad de Santa Fe y los indígenas de las fronteras Norte y Este, el poblamiento adquirió nuevas localizaciones y formas. Establecida la frontera Norte tras la negociación con abipones y mocovíes a "vivir en policía" en las reducciones de San Pedro, San Javier y San Jerónimo, se hizo necesario evitar los robos de ganado, por las avanzadas de chaqueños no reducidos, a las estancias de antigua colonización. En este sentido, se dispuso la creación de fuertes en los cuales radicar la población flotante demandante de tierras. Este hecho, a su vez, resolvía el problema de la radicación espontánea de los recién llegados en tierras ya ocupadas por los vecinos, pues se los alejaba a poblar los fuertes.

Respecto de la frontera Este, en 1749 el gobernador Andonaegui preparó una avanzada contra los indios Charrúas en "los entre ríos" y la Banda Oriental del Uruguay, en la que intervinieron tropas de Santa Fe, Corrientes, Buenos Aires, Montevideo y las Misiones guaraníes. El maestre de campo D. Francisco Antonio de Vera Muxica, teniente de gobernador de Santa Fe derrotó a los charrúas en 1750. Los sobrevivientes fueron reducidos en Concepción de Cayastá, lugar del sitio original de la ciudad fundada por Garay. Dos años más tarde, una segunda expedición extinguió la población indígena de la costa del río Uruguay. ${ }^{44} \mathrm{La}$ inexistencia de una política de radicación de fuertes en "la otra banda" puede ser explicada por ese factor. Los fuertes que se establecieron en el arco NO-NE de Santa Fe, sobre los ríos Salados — como se verá-, cumplirían la función de reubicar a su alrededor la población de migrantes, vagantes u ocupantes de tierras sin título, conteniendo el flujo hacia las tierras del Este del Paraná.

La expulsión de la Compañía de Jesús permitió que quedara una enorme extensión de campos entre los ríos Paraná y Gualeguay, objeto de diversas pretensiones. Por un lado, los vecinos santafesinos de arraigo en la Bajada, y por otro, los numerosos grupos de familias venidas en un proceso migratorio dinamizado por el crecimiento ganadero en el litoral.

El asentamiento de pobladores de Santa Fe, la Bajada y Corrientes en los pagos entrerrianos se consolidó mediante estrategias de estos nuevos vecinos insertas en los conflictos entre la autoridad civil-militar virreinal

44 Arce, Facundo: "El poblamiento", en Pedrazzoli, J. (director): Enciclopedia de Entre Ríos. Editorial de Arocena, Paraná, 1979. 


\section{MAPA N. ${ }^{\circ}$ 2: PRINCIPALES ESTANCIEROS DE LA CAMPAÑA SANTAFESINA: PAGOS DEL SALADO, LOS SALADILLOS, RINCÓN, CORONDA, ARROYOS Y LA BAJADA}

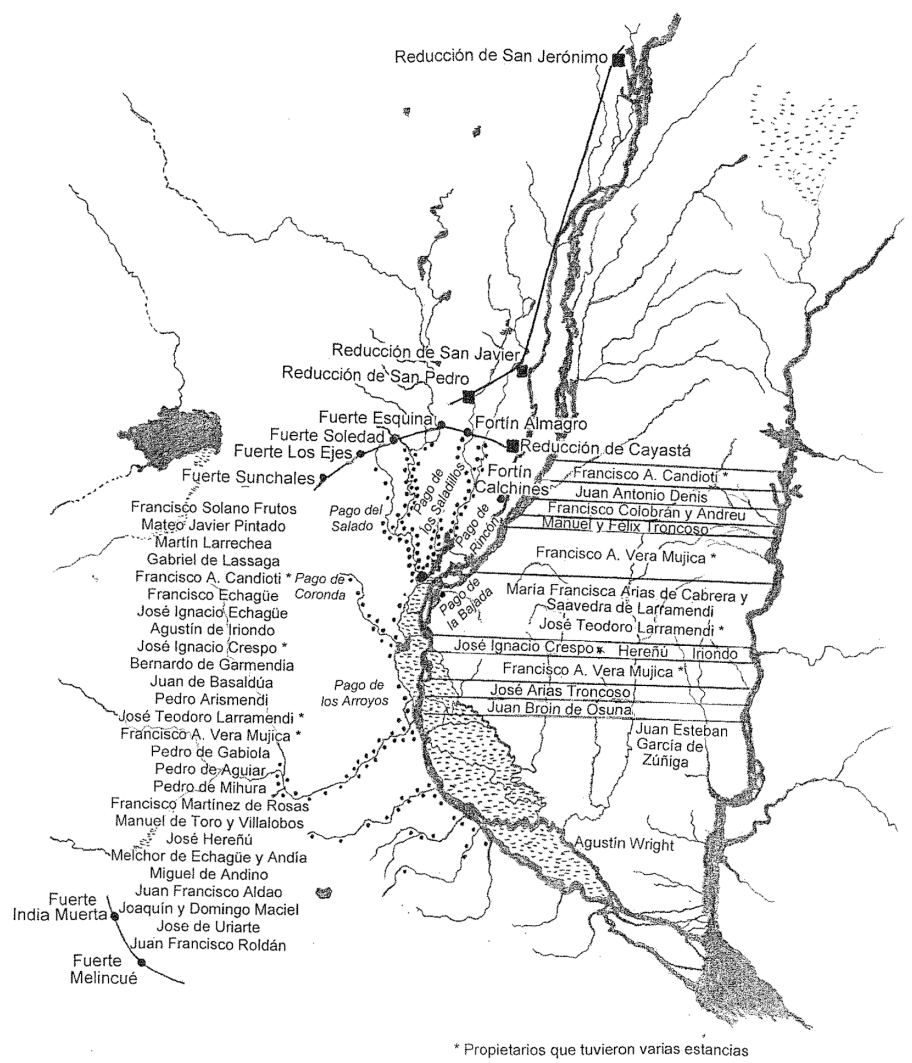

Principales Vecinos con tierras y ganados de Santa Fe. Estancias sobre las márgenes del río Salado y Saladillo en sus dos bandas, Pago de los Arroyos y río Carcarañá. Estancias de santafesinos con fondo al río Uruguay en los entrerríos. Estancieros de Buenos Aires en el sur de los entrerríos. Línea de fuertes en el Norte y SO. Reducciones jesuitas del siglo XVIII que continuaron existiendo como pueblos de indios después de 1767.

Fuentes: Mapa construido por las autoras a partir de: 1. Mapa de la década de 1790, titulado "Plano topográfico los que comprende desde la ciudad de Santa Fe al Norte hasta los fuertes de su frontera" en Cervera, Manuel: Historia de la ciudad y provincia de Santa Fe, 1573-1853, Imprenta La Unión, Santa Fe, 1907; 2. Facundo Arce: "El poblamiento: 1573-1776" en Enciclopedia de Entre Ríos, J. Pedrazzoli (Dir.), Edit. Arozena, Paraná, 1979, T.1, págs. 105 y ss.; 3. actas de cabildo del AGPSF y expedientes civiles del DEEC; 4. Pérez Colman, C.: Historia de Entre Ríos, Imprenta de la Provincia de Entre Ríos, Paraná, 1936, Tomo II; 5. Mapa del P.Cardiel, de 1752, en Furlong, Guillermo: Cartografía Jesuítica del Río de la Plata, Publicaciones del Inst. de Invest. Históricas de la UBA, 1936. 


\section{MAPA N. ${ }^{\circ}$ 3: FRONTERAS DE SANTA FE A FINES DEL SIGLO XVIII: VIEJOS Y NUEVOS NÚCLEOS DE POBLAMIENTO}

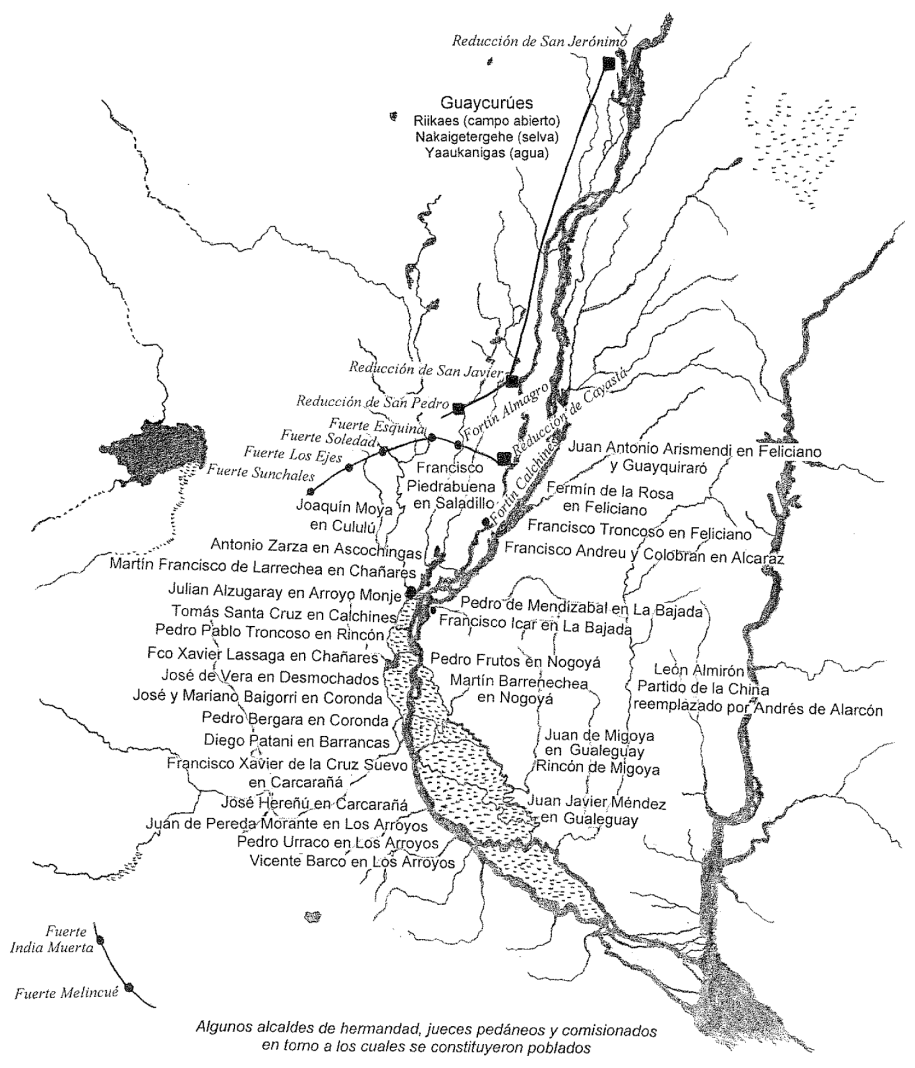

Poblamiento y medidas institucionales para el control de la frontera. Algunos alcaldes de hermandad, jueces pedáneos y comisionados en torno a los cuales se constituyeron poblados. Línea de fuertes en el Norte y SO. Reducciones jesuitas del siglo XVIII que continuaron existiendo como pueblos de indios después de 1767.

Fuentes: Mapa construido por las autoras a partir de listados y menciones de pobladores, jueces pedáneos y alcaldes de hermandad en el territorio santafesino-entrerriano que están documentados en: 1. actas de cabildo del AGPSF y expedientes civiles del DEEC; 2. Pérez Colman, C.: Historia de Entre Ríos, Imprenta de la Provincia de Entre Ríos, Paraná, 1936, Tomo II; 3. Cervera, Manuel: Historia de la ciudad y provincia de Santa Fe, 1573-1853, Imprenta La Unión, Santa Fe, 1907. 
y la autoridad eclesiástica hacia 1780. Los pedidos de formación de parroquias sobre la base de las capillas existentes por parte de nuevos pobladores en áreas de colonización reciente, disputadas por grandes hacendados y distintas jurisdicciones, cuestionaban las pretensiones de estos últimos de acaparar las tierras con ganado. Tales pedidos fueron fomentados por el obispo Malvar y Pinto, enviado por el rey para el reconocimiento de los pueblos y recursos de la región mesopotámica en disputa con Portugal, entre 1779 y 1784 . Durante su visita aconsejó a los pobladores que se dirigieran al virrey para demandar protección y pedir la formación de parroquias adonde antes existían capillas.

En 1779 más de cincuenta vecinos del partido de Gualeguay elevaron al virrey una petición semejante, expresando en ella sus temores de que D. Agustín Wright, comandante del partido y poseedor de estancia con capilla en el lugar, pudiera desalojarlos por la fuerza, como les constaba había hecho antes. ${ }^{45}$ En ella dicen:

"siempre estamos temerosos de que después de trabajar nos expulsen de las tierras, como continuamente estamos recibiendo amenazas de Don Agustín Wright, y que hasta la leña que hemos quemado la hemos de pagar; ahora que dicen que ha alcanzado el título de Comandante del Partido hará lo que al dicho le parezca con la Superioridad". ${ }^{46}$

En ella dicen también que están dispuestos a pagar precios equitativos por las tierras, a las que se consideran con derechos preferentes en su carácter de primeros habitantes que las conquistaron de los indios.

Un año antes, en 1778, D. León Almirón, juez comisionado nombrado por Santa Fe para el partido llamado Arroyo de la China, sobre el río Uruguay, hace una misma petición a nombre de su vecindario compuesto de treinta familias españolas y otras tantas de naturales ${ }^{47}$. Explica que desde que fueron "lanzados" violentamente por D. Esteban García de Zúñiga, poseedor de una de las mayores estancias atendida por esclavos y con gran cantidad de haciendas en el partido del Gualeguaychú, no tienen la asistencia espiritual que necesitan. En represalia, Almirón fue sustituido por

45 Pérez Colman, C.: Historia de Entre Ríos. T.2, cap. 4 y apéndice.

46 Citado en Pérez Colman, C.: Historia de Entre Ríos: Archivo General de la Nación (AGN), Tribunales, Legajo (en adelante Leg.) 252, Expediente (en adelante Exp.) 10.

47 La Rinconada del Arroyo de la China y el puerto de Incharrandiera pertenecían a un vecino de Santa Fe, D. Manuel Caraballo, que había obtenido sus derechos del cabildo de Santa fe. En 1775, ocupados estos campos con las 23 familias, Caraballo vendió sus títulos a D. Juan de Elía, vecino afincado de Buenos Aires. Al puerto llegaban carretas de las misiones, la Bajada y Santa Fe. 
D. Andrés de Alarcón en su cargo, en virtud de las órdenes del hacendado de Buenos Aires García de Zúñiga. ${ }^{48}$

Si bien estos reclamos estaban acompañados de una justificación religiosa y el temor de "morir sin el pan de la vida eterna", encerraban una estrategia de estos pobladores para asegurar la permanencia y estabilidad de su asentamiento, para no ser expulsados y, al mismo tiempo, volverse legítimos dueños de las tierras que ocupaban. A su vez, evidencia el conflicto jurisdiccional entre los cabildos de Santa Fe y Buenos Aires siendo que un juez pedáneo nombrado por el primero fue sustituido por otro designado por el segundo a instancia del poderoso García de Zúñiga. Finalmente, es significativo que el área en pleito esté sobre el río Uruguay, localización que permite el contacto con los mercaderes portugueses y una salida alternativa al océano Atlántico.

Estos pedidos generaron discrepancias entre el obispo y el virrey. El cabildo eclesiástico dio respuesta positiva a todos ellos al momento de su solicitud, pero el virrey Vértiz tardó dos años en aprobarlos, ya que implicaba reconocerles su derecho a las tierras. Un oficio del rey le ordenó hacer lugar a los pedidos del obispo. En 1781 el cabildo eclesiástico de Buenos Aires mandó los curas para las nuevas parroquias de Gualeguay, Gualeguaychú y Arroyo de la China. En los conflictos sobre jurisdicciones, que a su vez se dieron entre estos curas, intervinieron distintas autoridades: D. Juan Broin de Osuna comandante de Paraná, D. Melchor de Echagüe y Andía teniente gobernador de Santa Fe, D. Agustín Wright comandante del partido de Gualeguay, el virrey Vértiz y D. Tomás de Rocamora capitán de Dragones $^{49}$ dada la injerencia de las respectivas corporaciones. Los memoriales de los funcionarios borbónicos que en diferentes misiones recorrieron el área rioplatense, como es el caso de Azara o del mismo obispo Malvar y Pinto, mencionan el afán de concentración de tierras de propietarios absentistas que desplazan a las gentes dispersas y pobres. Con el objetivo de controlar esa acumulación de recursos y limitar el poder y autonomía de las elites locales, esos memoriales proponen "el arreglo de los campos" y sus redactores participan en los conflictos entre pobladores y grandes hacendados, asignando tierras a quienes las trabajan o se dedican a la ganadería, en detrimento de los propietarios absentistas que acumulan tierras ociosas..$^{50}$

48 Pérez Colman, C.: Historia de Entre Ríos, T.2, Cap 4.

49 Pérez Colman, C.: Historia de Entre Ríos, T.2, Cap. 4 y 5.

50 Barrán, José P. y Nahum, Benjamín: Bases económicas de la revolución artiguista, Segunda Parte "La revolución y la tierra", Ediciones de la Banda Oriental, 3ra. edición 1969 (1ra 1964), pág. 85 a 99. Los autores mencionan a García de Zúñiga como el más grande propietario a ambas márgenes del río Uruguay. 
Los mencionados reclamos por tierras indican los cambios que tiene el fin de siglo en este espacio regional. Por un lado, ha comenzado a confrontar el antiguo principio colonial de ocupación espontánea con usufructo de tierras, pastos y aguadas, con el nuevo derecho de propiedad mediante título. Asimismo, la demanda por tierras de estancia en lugares de antiguo poblamiento como los pagos del Salado, Cululú, Coronda y los Arroyos se amplía, en las últimas décadas del XVIII, a la otra banda del Paraná: "los entre ríos". La particularidad que tuvo el proceso explicado fue una mayor distribución de las tierras al Oeste del Paraná. En la otra Banda, unos pocos vecinos se apropiaron de grandes extensiones, por lo cual los ocupantes de las nuevas poblaciones entrerrianas - Gualeguay, Gualeguaychú y Arroyo de la China - sólo fueron adjudicatarios de solares urbanos. Finalmente, la asignación de tierras en "los entre ríos" ya no fue hegemónicamente hecha desde el cabildo de Santa Fe, sino también desde el de Buenos Aires y los de las tres poblaciones mencionadas.

\section{De controles y resistencias}

La recepción de estos nuevos pobladores en Santa Fe generó reacciones de todo tipo por parte de los vecinos hacendados. Una actitud de rechazo se exhibió ante las familias inmigrantes tomando la forma de calificativos en el lenguaje expresando el malestar social que producía la ocupación de ciudad y campaña. Algunos términos para referirse a ellos son "vagabundos", "malévolos", "ladrones", "cuatreros incorregibles", "gauderios", "ociosos", "malhechores", "malentretenidos", "facinerosos" mente conociendo estas opiniones adversas hacia ellos, es que en sus informaciones matrimoniales - dadas al cura previamente a contraer matrimonio- estos itinerantes ponen como testigos de su soltura a sus empleadores, vecinos respetables, en lugar de sus propios pares como en décadas anteriores. Refuerzan los datos de cuánto hace que trabajan con tal vecino, mencionan otros amos, se esfuerzan por parecer confiables. La insistencia de los migrantes por parecer reconocidos y avecindados desde largo tiempo en el lugar muestra que aquellos sujetos estaban en conocimiento de la repulsa que producían los vagantes. Se resistían a ser sospechados, estigmatizados como vago, intruso, delincuente.

51 Suárez, Teresa: "Los migrantes en búsqueda de reconocimiento en la villa de Santa Fe", Jornadas de Historia Económica, Universidad de Quilmes, 1998. 
Junto con la estigmatización, la actitud de rechazo tomó también la vía de la criminalización de estos sujetos. ${ }^{52}$ La criminalización de la vagancia se dio en la medida en que se produjo una progresiva asociación vagoladrón-cuatrero, de una larga historia en la tradición castellana medieval, pero que hacia fines del siglo XVIII no se refería solamente a los hombres "solos y sueltos" "sin bienes de subsistencia", sino también a los pequeños productores diseminados por la campaña (hogares campesinos que disponen de algunos bienes). La vagancia pasó a ser una figura jurídica muy laxa: incluía personas sin domicilio fijo, desertores, ocupantes sin títulos, agregados, peones sin papeleta de conchavo o pasaporte, ebrios, mendigos de "falsa pobreza" o jugadores de juegos prohibidos. ${ }^{53}$ Una misma pena, como la establecida por real orden de 7 de mayo de 1775 que ordenaba la leva militar de vagos y ociosos, unificó dos modos de vida antes diferentes: los desposeídos de bienes que no tenían "ocupación lícita" (ociosos) y los que teniéndolos llevaban una vida "de malas costumbres" (malentretenidos, amancebados).

En la imagen de la campaña que poseía la élite, la vagancia ocupaba un lugar relevante. La figura no sólo es presentada como netamente criminal, sino que esta criminalidad se define por el modo de vida "perjudicial", antes que en cualquier hecho cometido. Un andamiaje jurídico renovado y la recomposición de instituciones de control se orientó hacia el "sosiego de la campaña".

Los documentos capitulares sugieren también un crecimiento numérico de los habitantes de la ciudad. Se menciona una nueva "multitud" de transeúntes, viandantes, forasteros, mercachifles, hombres y familias en general, que llegan del interior y pululan en la ciudad y el campo llevando una vida "escandalosa y perniciosa" que abruma a la gente decente y autoridades. Según los vecinos, esa población, menospreciable por "haragana, sucia y supersticiosa" se afinca desordenadamente, sin mayores trámites, en los espacios de la ciudad, marcando el ambiente reinante en sus calles. Por ello, la ciudad trató de ordenarlos con sus fiestas, procesiones, diversiones y juegos permitidos, en el ambicioso intento de disciplinarlos en unas prácticas sociales que pretendían ser consagrantes de la jerarquía y

52 Tornay, María Laura: "La justicia rural en Santa Fe colonial. Cambios institucionales y sociales en el período borbónico", IV Encuentro de Historiadores de la Junta Provincial de Estudios Históricos de Santa Fe, septiembre de 2002.

53 Fabián Alonso, María Elena Barral, Raúl Fradkin, Gladis Perri: "Los vagos en la campaña bonaerense. La construcción histórica de una figura delictiva (1730-1830)" en Prohistoria , N. ${ }^{\circ}$ Historia y Antropología jurídicas, 5, Año V, Rosario, Argentina, 2001. 
que buscaban, en definitiva, enseñar un modelo de vida urbana poco enraizado en estas sociedades mercantil-ganaderas. ${ }^{54}$

"Los montes", "los chañares", constituyen un lugar al que los documentos asignan una carga negativa, por ser refugio de los no-vecinos. Se presenta la paradoja de ser éste un lugar que se encuentra dentro de los límites del dominio jurisdiccional español pero que a su vez constituye otra frontera, otra cultura, compuesta por esta población sin trabajo o sin relación de dependencia que se mueve de un lugar a otro y se sustrae del mercado laboral.

Jesuitas como Dobrizhoffer advertían el múltiple sentido que los montes tienen para los distintos actores: lugar hostil para los españoles, lugar de protección para los indígenas y lugar de evangelización para los misioneros. ${ }^{55}$

\section{Las medidas institucionales}

Las autoridades locales debieron resolver qué destino daban a los recién llegados. Tras la pérdida del rol distribuidor de las producciones regionales que Santa Fe tenía con el privilegio del "puerto preciso", hacia 1770 los sectores mercantiles redefinieron sus estrategias económicas por la vía de la producción y comercialización ganadera. Si bien fue el ganado y no la tierra la principal fuente de inversión en las estancias coloniales, la nueva coyuntura ganadera condujo a las elites a un mayor celo en el cuidado de las haciendas y a una consideración más estricta de la ocupación de aquélla. Especialmente para los sectores subalternos, la "frontera abierta": acceso a medios de subsistencia, circuitos clandestinos de comercialización, acceso a la tierra ${ }^{56}$, parece haber llegado a su fin. A fines del siglo XVIII, los hacendados ya no toleraban

“...la libertad con que cada cual sin el menor empacho ni recelo ha usado y usa de los ganados ajenos...". ${ }^{57}$

54 Tornay, María Laura: Informe final de Cientibeca: "Gente de mal vivir y gauderios de profesión. El juego y las diversiones públicas en la ciudad y campaña santafesina. 1770-1810”, UNL, 1998.

55 Armando, Adriana: "Un acercamiento al Chaco Austral a mediados del S. XVIII. El relato de Dobrizhoffer y los conflictos fronterizos", Anuario IEHS, N. . 9, Tandil, 1994, p. 215.

56 Mayo, Carlos: "Sobre peones, vagos y malentretenidos: el dilema de la economía rural rioplatense durante la época colonial", Anuario IEHS, N ${ }^{\circ}$ 2, Tandil, Univ. Nacional del Centro de la Pcia de BsAs, 1987.

57 AGPSF, AC, 10 de diciembre de 1777, T.XIV, fs. 121-123. 
Su preocupación tiene que ver además con un dato importante para el futuro predominio ganadero en la región, el precio creciente de los cueros, por lo cual demandaban que

“...con el motivo de ir tomando alguna estimación los cueros, y haber algunos compradores de ellos en esta ciudad, se arregle un método de reconocimiento para asegurar el que no se experimente el daño de que los que no son legítimos dueños se pongan a hacer matanzas de ganados ajenos y vender los cueros a los compradores....". ${ }^{58}$

Así, los vecinos hacendados vieron en los recién llegados un peligro y arbitraron mecanismos tendientes al "cierre" de la frontera. Este hecho hizo que parte de dicha política vaya dirigida contra esta ocupación indeseada. Una serie de medidas institucionales se derivaron de las problemáticas presentadas. Designaciones de jueces pedáneos, del comandante de la Frontera, instrucciones a los alcaldes de la Santa Hermandad, a la tropa y a los vecinos sobre los traslados de familias a los fuertes, a las reducciones o su expulsión, constituyeron las medidas más frecuentes.

El cabildo intentó reordenar esa población de orígenes diversos y trasladarla a la zona de fuertes para que allí, bajo el control de la autoridad, se estableciera "en sociedad" en un intento de homogeneizar el espacio español de acuerdo a un orden social deseable que se extendiera hasta los confines mismos de la jurisdicción. Pero, además, el traslado compulsivo de población vagante, poco estable o que no pudiera demostrar antigüedad de asentamiento, hacia los fuertes en el último cuarto de siglo, fue una medida tomada para erradicar de las estancias a los sujetos y familias sospechados de ocupar tierras ajenas como productores autónomos y volverse competidores económicos de la elite. El cabildo, amparado en el gobernador intendente y el ahora cercano virrey, e interesado en el gobierno económico de los partidos de esta jurisdicción, dispuso:

"...que todas las familias que se han trasladado de las mencionadas ciudades interiores a esta jurisdicción se pongan en esta frontera al costado o línea de los mismos fuertes donde formen villas, y así mismo varias familias de estos partidos a quienes no se les conoce hacienda de que resulte procreo para su subsistencia, motivo que hace sospechosa su conducta, que igualmente se trasladen a aquel destino donde se establezcan, de que resultará el beneficio que está a la vista de fortificar la frontera y recoger las familias dispersas y el desembarazo de los hacendados ....". ${ }^{59}$

58 Saeger, James: “Another View...”.

59 AGPSF, AC, 13 de noviembre de 1786, T. XV, f. 198. 
La institución protegía los derechos a la tierra y los ganados de los vecinos principales frente a los nuevos pobladores independientes, no "agregados", y "sin dominio de propiedad en los terrenos que ocupan". Su reubicación en las cercanías de los fuertes de la frontera se llevó cabo con el objetivo de ponerlos bajo la mirada de la autoridad militar ya que "al ánimo de los fuertes estarán más distantes de cometer excesos" y de contenerlos "dentro de los límites de población en sociedad". ${ }^{60}$

Con este objetivo, la frontera Norte de Santa Fe desde el Paraná hasta el límite con Córdoba, que a mediados del siglo se cubría con tres reducciones de aborígenes guaycurúes sometidos, fue reforzada - ¿o sustituida? - con cinco fortificaciones y su correspondiente guarnición militar. Así, a fines del siglo XVIII se levantaron Melincué en la frontera Sur, y en la Norte cuatro fuertes y un fortín que el teniente de gobernador Prudencio María de Gastañaduy mandó construir en la línea que iba desde Sunchales hasta San Javier. La mayoría de las fortificaciones en las fronteras con los indígenas eran llamadas fortines o cantones, simples construcciones de barro y paja cercadas con una empalizada o terraplén de tierra. Las grandes fortalezas no abundaban en el Río de la Plata; donde las había, constituían el asiento de la comandancia de fronteras. En los alrededores de los fuertes y fortines se levantaban los ranchos de las familias de los militares y pobladores trasladados, y se les asignaban tierras para el mantenimiento de la caballada y el sembrado de maíz. ${ }^{61}$

Entre 1789 y 1793 Gastañaduy trasladó más hacia el Norte los fuertes existentes de San Juan Bautista (antes del Salado) unas diez o doce leguas, y San Nicolás (antes La Pelada) otras cuatro; también trasladó el fuerte del Tío, en la frontera con Córdoba, a las cercanías del camino entre Santa Fe y Santiago del Estero por los Porongos. En esos años Gastañaduy finalizó la construcción del fortín sobre el Saladillo y construyó los fuertes de Almagro junto al Saladillo Amargo; el de Feliú o San Prudencio (conocido como el de la Esquina) sobre la esquina o Vuelta Grande del Salado; el de Soledad o Arredondo en Rincón del Quebracho (los restos actuales de gruesos ladrillos cocidos dan una idea de la importancia de la fortaleza). A su izquierda construyó en 1790 el fuerte de los Unchales o Sunchales, cono-

60 AGPSF, AC, 22 de octubre de 1794, T. XVI, fs. 279-288.

61 Aleman, Bernardo: Santa Fe y sus aborígenes, T. I. El tipo de poblamiento, construcciones y actividades de estos fuertes ha sido trabajado en El problema del indio en la historia de Santa Fe, Comisión Redactora de la Historia de las Instituciones de la Provincia de Santa Fe, Santa Fe, 1970, T. 3, pág. 39. 
cido como el de la Virreina (también sus restos materiales evidencian la importancia del asentamiento: tenía capilla, mangrullo, casas de vivienda y galpones, como los demás). El fuerte Melo, ubicado en la cañada de los Ejes entre el de Soledad y el de Sunchales, fue levantado en 1799 para completar el arco, cuyo radio distaba de quince a veinte leguas de la ciudad. Se sumó a esta línea de fuertes el de San Juan Napomuceno en Calchines. Al fuerte de Cululú le aumentaron su defensa en 1780. Estos fuertes se agregaban a los guarnecidos por Santa Fe en la frontera con Buenos Aires durante el gobierno del virrey Cevallos (1776-78): el de Melincué, India Muerta, Las Tunas y Puntas del Sauce, y otros menores como el de Pavón. Entre las décadas de 1780-90 los fuertes existentes, trasladados y nuevos, se poblaron con los ex residentes de las misiones jesuitas y con las familias recién llegadas. ${ }^{62}$

Podemos advertir cierta efectividad en la política de traslado compulsivo de población a las fronteras. El fuerte de Sunchales tenía para 1799 (a menos de una década de su creación en 1790) unos 1113 habitantes. ${ }^{63}$ Políticas similares se llevaron a cabo en otros puntos del virreinato del Río de la Plata. El censo de 1782 en la Villa de la Concepción de Paraguay contabilizaba 908 habitantes en ella, y el de 1799 unos 2227 habitantes, lo que hace un aumento del 145,26\% en 17 años. Ese crecimiento se dio en el marco del auge yerbatero paraguayo, mediante el reclutamiento forzoso de milicianos y el establecimiento obligatorio para los sin tierra. ${ }^{64}$ En Córdoba, el control creciente sobre la población que se ejerció desde la Gobernación Intendencia buscó atacar la movilidad de la población rural con medidas similares a las tomadas por la elite dirigente santafesina: traslados compulsivos de población a los fuertes, nombramientos de jueces pedáneos, exigencia de la papeleta de conchavo, etc. Aquí también la fundación de villas y la política de fronteras no parece obedecer a una situación de guerra con el indio.

El traslado de población a los fuertes interesó a los vecinos hacendados de Santa Fe por motivos económicos específicos. Los migrantes y productores independientes asentados en tierras ajenas eran vistos por esos vecinos no sólo como elementos insumisos y móviles, sino además como

62 Aleman, Bernardo: Santa Fe y sus aborígenes, págs. 149-155.

63 Cervera, Manuel: Historia de la ciudad y provincia de Santa Fe, T. 1, pág. 562. Aunque no sabemos la fuente de tal cifra, su precisión hace suponer un recuento de población en el fuerte.

64 Areces, Nidia: "Tierra y frontera - Concepción (Paraguay 1773-1840)" en Anuario UNR, N. ${ }^{\circ}$ 17, Rosario, Argentina, 1995-96. 
competidores económicos en una escala difícil de precisar cuantitativamente, pero evidente en las preocupaciones de aquellos hacendados que dominaban los circuitos comerciales más importantes y el abastecimiento a puntos clave como la ciudad y los fuertes. El abastecimiento de carne a los fuertes se convirtió en un buen negocio. D. Juan Francisco Aldao, vecino regidor decano del cabildo de Santa Fe, mediante una presentación del Intendente de Ejército y Real Hacienda en 1778, solicitó tomar a su cargo el racionamiento de las tropas de los fuertes de India Muerta y Melincué - protectores de los indios Pampas- y los de la frontera Norte, Fuerte Grande del Cululú y Arroyo Rabón - protectores de los indios del Chaco- a un valor de real y medio la ración. Hacía el ofrecimiento en su condición de hacendado y poseedor de ganado y siembra.$^{65}$ Asimismo, en 1793, cuando se había instalado en el norte de Santa Fe una nueva línea de fuertes, el comandante de armas Prudencio María de Gastañaduy pidió se le concediera con exclusividad el abasto de carne para la ciudad y los fuertes por cinco años, propuesta discutida por otros cabildantes interesados en el comercio de ganado. ${ }^{66}$ Las instrucciones elaboradas por el teniente de gobernador para el gobierno y régimen de las fronteras tuvieron en cuenta la opinión de esos vecinos hacendados. ${ }^{67}$

El traslado de los fuertes unas leguas más al Norte de la ciudad entre 1790 y 1793, también obedeció al interés de quienes dominaban el comercio hacia Córdoba y Perú en abrir nuevas rutas y consolidar las existentes hacia estos puntos ${ }^{68}{ }^{6 l}$ pedido de erigir un fuerte en el paraje Los Altos o Monigotes, al Norte de Sunchales, para completar la línea de fuertes hacia el Chaco, si bien no realizado, evidenciaba esas motivaciones. ${ }^{69}$

65 Departamento de Estudios Etnográficos y Coloniales (en adelante DEEC) Expedientes Civiles (en adelante Exp. Civ.), T. 39, folios 79-104, años 1778-9.

66 AGPSF, AC, 5 de noviembre de 1793 y 11 de noviembre de 1793, T. XVI, fs. 223-232.

67 Entre julio y agosto de 1796 fueron consultados los vecinos Francisco Antonio Candioti, Gabriel de Lassaga, Vicente Zabala, Agustín de Iriondo, Bernardo de Garmendia, Ignacio Crespo, José Ignacio de Echagüe, Antonio Zarza, Vicente Forcada y Juan de Cabrera. Todos se conformaron con la propuesta del gobernador. AGPSF, AC, julio-agosto de 1796, T. XVI, fs. 395-406.

68 En 1790 los miembros del cabildo discuten acerca de lo útil o perjudicial del proyecto de avance sobre el Chaco mediante la navegación del Bermejo y la creación de fuertes en sus orillas, en el camino de Santiago y el camino de Córdoba. AGPSF, AC, 2 de junio de 1790, T. XVI, fs. 65 v -71.

69 Informe del Procurador Larramendi, hacendado y comerciante de Santa Fe, ante el Consulado de Buenos Aires, en 1795. En el análisis de situación que presenta de Santa Fe para reclamar la devolución del privilegio del Puerto Preciso, remarca el estado mísero de la ciudad y menciona unas incursiones indígenas de 1792 que alcanzaron a estancias situadas hasta ocho leguas próximas a la ciudad, en las que se robó hacienda, destruyó casas y degolló mas de treinta vecinos. Como solución, planteó este nuevo fuerte. En: Cervera, Manuel: Historia de la ciudad y provincia de Santa Fe, Apéndice XXVII, T. 3, pp. 473-485. 
Por otro lado, si estos fuertes cumplían la función de reubicar a su alrededor la población de migrantes, vagantes u ocupantes de tierras sin título, conteniendo el flujo hacia las tierras del Este del Paraná, también le aseguraban a los vecinos que acapararon tierras para haciendas en "los entrerríos", que no tendrían competidores ni observadores de su comercio legal o ilegal por el río Uruguay hacia Montevideo o el Brasil.

La intervención del virrey como ejecutor de la política borbónica, al igual que la participación del comandante de armas muestran acciones coordinadas y respaldo real a las acciones locales, como queda testimoniado en los documentos sobre el traslado de familias de Coronda al fuerte de Soledad ${ }^{70}$. Su sustento quedaría provisto por el fondo de arbitrios del cabildo hasta que pudieran trabajar y adquirir lo necesario para sustentarse a costa propia. Gastañaduy previó que lo mismo estaría dispuesto para

"las familias que en lo sucesivo se arraiguen en dichas fronteras". ${ }^{71}$

La referencia a "que en lo sucesivo se arraiguen" podría indicar que los hacendados y autoridades percibían claramente que este fenómeno inmigratorio era prácticamente incontrolable y seguiría aumentando.

En medio de las discusiones sobre el traslado de los fuertes más avanzados, cobraron notoriedad la Compañía de Blandengues y el Alcalde de la Santa Hermandad, instituciones que reforzaron su autoridad en este período borbónico. El empleo de la fuerza para los continuos traslados de familias procedentes de Córdoba, Santiago del Estero y Tucumán, hizo necesario el refuerzo de instrucciones a la tropa. Asimismo quedaron habilitados para implementar la expulsión el Alguacil Mayor y el Sargento Mayor. ${ }^{72}$

El fortalecimiento del aparato militar a partir de las Ordenanzas de Carlos III de 1768 fue un hecho común a la metrópoli española y a toda América. Ella significó la reorganización de las milicias, su formación profesional y el establecimiento riguroso de las jerarquías, honores y funciones dentro del personal militar veterano y estacional. ${ }^{73}$ Los Blandengues de la Frontera santafesinos creados en 1724 son las primeras unidades de milicias del Río de la Plata y el antecedente de las creadas en Buenos Aires en

70 AGPSF, AC, 9 de diciembre de 1794, T. XVI, fs. 291-292.

71 AGPSF, AC, 9 de diciembre de 1794, T. XVI, fs. 291-292.

72 AGPSF, AC, 21 de agosto de 1786, T. XV, fs. 191-2; AC, 22 de diciembre de 1793, T. XVI, fs. 241.243 .

73 Bidondo, Emilio A: "Las tropas del Río de la Plata bajo la influencia de la legislación militar borbónica”, en Investigaciones y Ensayos, A.N.H., N. ${ }^{\circ} 32$, Buenos Aires, enero-junio de 1982. 
1760. Ambos fueron elevados en la década de 1780 a la categoría de tropas veteranas y por tanto comenzaron a gozar de los mismos derechos y obligaciones que las tropas venidas de la metrópoli.

En este marco en que se otorgan nuevos títulos, en Santa Fe el cabildo decidió que el Capitán de la compañía, con título de comandante de la Frontera, comandante de Armas y/o comandante de los Vagos, reuniera las familias vagantes e indios de las reducciones en las inmediaciones de los fuertes..$^{74}$ En 1792 el virrey Arredondo envió a Santa Fe al sargento mayor Francisco Balcarce para reorganizar las milicias y el cuerpo de Blandengues. En poco más de tres meses reorganizó las dos compañías de Blandengues y cinco de milicias urbanas. En sucesivos acuerdos los vecinos propusieron listas diferentes de candidatos hasta conformar la nueva jefatura del creciente aparato militar. Entre los nombrados aparecen conocidos vecinos: Arizmendi, Larrechea, Villamea, Echagüe, Espeleta, Iriondo, Baigorri, Suero, Baez, Ríos, Roldán, Avechuco, Vergara, Basaldúa, Zarza, Piedrabuena, Leiva, Redruello, entre otros, muchos de ellos jueces pedáneos o alcaldes de hermandad en sus partidos. ${ }^{75}$

En esta transición organizativa militar en que los Blandengues constituyen una nueva institucionalidad militar, las milicias de vecinos a la vieja costumbre continúan actuando en defensa de sus intereses, aunque legitimadas por la renovada presencia del alcalde de la santa hermandad. En documentación capitular se prueba que vecinos de Coronda, organizando una acción coactiva privada, salen a controlar las invasiones de los migrantes de Córdoba, quienes aprovechando la no laborabilidad de los feriados religiosos, se aproximaban a robar ganado. El alcalde de hermandad de Coronda permitió

“...al Sargento Miguel Gerónimo Cabral con 14 soldados vecinos honrados para que corran (de) estas campañas... la gente que de Córdoba se introduce a ella a arrear las haciendas con capa de potreadores escogiéndose los días santos para semejante empresa....".76

Las actuaciones del alcalde de hermandad también se orientaron hacia esta nueva política de fronteras. Los vecinos se comunicaban con él, llegando a contribuir con el traslado y asentamiento en la línea de fuertes. En abril de 1789, los vecinos de Coronda aportaron recursos a su Alcalde

74 AGPSF, AC, 4 de abril de 1789, T. XV, fs. 364-368.

75 AGPSF, AC, 28 de junio de 1792, 30 de junio de 1792 y 2 de julio de 1792, T. XVI, fs. 141-156.

76 AGPSF, Varios Documentos, 9 de mayo de 1791, fs. 32-34. 
“... para la erección y fomento de la villa o población que han representado por conveniente en el Arroyo de las Ovejas, compuesta de aquella gente perniciosa en su partido y que no tienen establecimiento propio en él ni haciendas bastantes con qué mantenerse...." ${ }^{77}$

En este ordenamiento jurídico institucional, surgen con fuerte presencia los jueces pedáneos y comisionados rurales. El intento de control de la población rural tomó la vía de la persecución de la "vagancia" a través de su represión, tarea de los jueces "pedáneos" quienes entre sus facultades, detalladas en un acta de marzo de 1789, debían:

“...cuidar, velar y vigilar precisamente sobre la persecución y exterminio de todos los ladrones y gente perniciosa que se hallen y se encuentren estén establecidos en todo el distrito que abraza sus nombramientos, aprehendiéndolos y remitiéndolos a esta ciudad a disposición de cualquiera de los dos juzgados con el correspondiente parte en que expresen sus débitos, poniendo en poder de cualquier vecino de notorio abono todos los bienes que se les embargase." ${ }^{\prime} 8$

Desde esta fecha en adelante se irían nombrando cada vez más jueces en los distintos pagos.

Otra medida complementaria al traslado, fue la expulsión. En efecto, algunos vecinos de los Arroyos pedían

“...se mande desalojar todas las personas que se hallaron pobladas en las cañadas Rica y de la Calzada por el perjuicio que causan a todas las haciendas que pastan en ellas...". ${ }^{79}$

En tierras de la otra banda del Paraná, territorio identificado por los vecinos como peligroso por el asentamiento de "forajidos, malentretenidos, fugitivos, ausentados, viandantes..." que encontraban abrigo en estos lugares, los grandes propietarios aconsejaban "persecución y exterminio" ${ }^{80}$. En realidad, se debía al interés de éstos por controlar la salida al Atlántico de los productos de la ganadería por el río Uruguay. ${ }^{81}$

Las medidas institucionales analizadas constituyeron las respuestas que la elite santafesina tuvo que dar a los nuevos pobladores rurales, pero

77 AGPSF, AC, 20 de febrero de 1789, T. XV, fs. 348-352.

78 AGPSF, AC, 30 de marzo de 1789, T. XV, fs. 358-364.

79 AGPSF, AC, 2 de mayo de 1776, T. XIV, fs. 398-402.

80 AGPSF, AC, 2 de septiembre de 1793, T. XVI, fs. 204-207.

81 Barrán, José P. y Nahum, Benjamín: Bases económicas... 
también a los cabildos de las ciudades vecinas con las que a finales del siglo XVIII tuvo una serie de conflictos jurisdiccionales.

Los fuertes garantizaron la ocupación santafesina en puntos distantes de la ciudad. En la frontera de Buenos Aires se establecieron los fuertes de Melincué, India Muerta y Pavón, comenzados a construir en 1776. El fuerte de Melincué fue terminado en 1779, existiendo ya en septiembre del mismo año cuarenta casas para pobladores, cuarteles, iglesia, faltando sólo el puente levadizo. El de India Muerta fue fundado el mismo año. Para ambos, en 1779 se arrendó por cinco años a vecinos de Santa Fe la provisión de carne. Aunque esos fuertes dependían supuestamente de Buenos Aires (un documento del 31 de marzo de 1782 levantado por el comandante de frontera Francisco Balcarce y las Memorias del virrey Cevallos así lo mencionan), eran defendidos por guarniciones santafesinas. Según consta en la nómina de soldados existentes en el AGPSF en libros de Contaduría, se hallan anotaciones de cuentas respecto de los fuertes Melincué e India Muerta en los años de 1778 a 1780, pagando la tesorería de Santa Fe cien pesos mensuales al capellán de India Muerta, y otras cantidades mensuales para víveres de la guarnición. ${ }^{82}$

También la designación de jueces pedáneos tuvo que ver con esta puja entre jurisdicciones por establecer dominio en pagos remotos considerados propios. El cabildo de Santa Fe designó comisionados en aquellos lugares donde la importancia de la población, la llegada de vecinos de otras provincias, el ganado y el comercio lo requerían. Así nombró jueces en puntos distantes como el Arroyo de la China sobre el río Uruguay y en Alcaráz y Feliciano al Norte de Entre Ríos. En Gualeguay fue designado juez comisionado Juan Javier Méndez, un correntino establecido con sus ganados ya en 1768, en las proximidades de las tierras ocupadas por acaudalados estancieros de Buenos Aires. Méndez fue nombrado juez en 1772 y continuó como tal hasta 1782, por lo menos ${ }^{83}$. Sobre la costa del Gualeguay, Don Juan de Migoya fue nombrado juez pedáneo en 1800, en el lugar donde solicitó tierras (1795) y formó su estancia (1807), y que aún conserva su nombre, el Rincón de Migoya, partido de Diego López. ${ }^{84}$

82 El fuerte de Melincué fue terminado por Juan González el 25 de octubre de 1779 y el de India Muerta por el capitán Jaime Viamonte, según el Dr. Quesada, "Revista de Buenos Aires”, T. 5, págs. 41 y subsiguientes, citado por Cervera, Manuel: Historia de la ciudad y provincia de Santa Fe, T. 1, págs. 557-558.

83 Pérez Colman, C.: Historia de Entre Ríos, T. 2, pág. 53.

84 DEEC, Exp. Civ., T. 49, Leg. 666, 25 de septiembre de 1800, fs. 50v-51v.; Archivo General de la Provincia de Entre Ríos (AGPER), Gobierno, Serie VIII, Tierras, Carpeta N. ${ }^{\circ}$; Pérez Colman, C.: El Nordeste de Entre Ríos. 
Que esta política de expulsiones y traslados de pobladores se llevara a cabo, no necesariamente implica que fuera pasivamente aceptada por los mismos. Muchos de ellos resistieron las medidas y demandaron documentándose ante las autoridades. Es el caso de Juan Alberto Peralta, quien pleitea más de dos años ante el alcalde de segundo voto Juan de Morante por la devolución de su familia, trasladada en su ausencia, en forma compulsiva al fuerte Soledad. Peralta esgrime como argumentos que tiene desde hace veinte años estancia poblada en el Carrizal — partido de Corondacon casa, corral, ganados mayores y menores y labranzas con las que se sustentan él y su familia. Es evidente que Peralta conoce la jurisprudencia o se hizo asesorar por un letrado, ya que esgrime razones y derechos. Habiendo Peralta llegado hasta el virrey, le fue concedida la licencia para el reintegro de su familia. ${ }^{85}$ También en orden a eludir ser confinados a lugares no deseados, algunos asentamientos espontáneos podían cubrir ciertas formalidades legales como la previa solicitud del permiso correspondiente para quedarse en un sitio. Don Pedro de Morales plantea una petición semejante para mantenerse con su población en el paso del río Corrientes de esta banda, con la promesa de cuidar todo lo que sea "de robos y vagabundos". ${ }^{86}$

\section{Consideraciones finales}

En el último cuarto de siglo XVIII se asiste a un proceso de reacomodamiento de las áreas de población y de control efectivo de la ciudad de Santa Fe: menor peso misional, mayor poblamiento de fuertes, reasignaciones de tierras de estancias, fundación de capillas y ampliación de la justicia rural. Todas estas medidas reforzaron no sólo el dominio de las tierras al occidente del Paraná, de más antigua ocupación, camino del Alto Perú; sino también en las de "la Otra Banda", espacio de vaqueo temprano, de rodeo luego y finalmente de estancia de los vecinos santafesinos.

Si bien se reconoce en Santa Fe, entre 1770-1800, un área fronteriza de control incompleto, se está lejos de advertir una guerra abierta contra el indio como rasgo predominante de la política de fronteras. Se presentaron algunas hipótesis acerca de las modalidades con que las autoridades inten-

85 DEEC. Exp. Civ., T.45, 1796, Exp. 600, fs. 448-454.

86 AGPSF, AC, 6 de marzo de 1775, T. XIV, f. 361. 
taron ampliar su control de la campaña, poblada con los indígenas que paulatinamente abandonaron las misiones de San Jerónimo, San Javier y San Pedro, y con grupos o familias de inmigrantes que provenían de Córdoba, Tucumán y Santiago del Estero.

Se procuró ampliar la percepción acerca de la diversidad étnica y socioeconómica de los integrantes de las sociedades de fronteras, y acerca de la relación entre los guaycurúes libres y los reducidos en las últimas dos décadas del siglo XVIII.

Se reforzó la hipótesis que el recurso de trasladar la población a los fuertes, más que prevenir ataques indígenas, se hizo para dar un destino a los ocupantes sin título en la campaña, evitando su asentamiento en tierras de los vecinos, próximas a la seguridad de la ciudad y a las rutas de comercialización. Así, al control de las reducciones o "pueblos en policía" desde las décadas de 1740 y 1750 hasta fines de siglo, se agregó el de los fuertes de frontera desde 1780. Los pobladores de reciente ocupación de diversa procedencia estarían así inhibidos de disputar a los vecinos el comercio del ganado, principal recurso económico.

El variado conjunto de medidas institucionales tomadas por los vecinos santafesinos, presionados por las actividades autónomas llevadas a cabo por las "gentes indeseables", contribuyeron asimismo, a asegurar la ocupación de la jurisdicción pretendida, disputada por los cabildos de Córdoba, Buenos Aires y Corrientes.

De todas maneras, los sujetos afectados por estas medidas, aún en un marco de cierre de la "frontera abierta", buscaron los modos de resistir el traslado y la vigilancia para preservar su autonomía y sus formas de vida. Así, la política de fronteras diseñada por la elite en Santa Fe —el conjunto de vecinos que controlan el cabildo- consistió a la vez en la imposición y la negociación con los sectores subalternos, al tiempo que aceptaba y hacía un particular uso de los mecanismos e instituciones creadas o reforzadas con la política borbónica. 


\section{Apéndice}

LISTADO DE POBLACIONES DE FELIX DE AZARA. FINES DEL SIGLO XVIII

\begin{tabular}{lcc} 
Nombre & Antigüedad & $N^{o}$ de almas \\
\hline Santa Fe & 1573 & 4000 \\
San Fco. Javier & 1743 & 1308 \\
San Jerónimo & 1748 & 482 \\
Cayastá & 1749 & 67 \\
Ynspín & 1795 & 600 \\
Arroyo de la China & 1780 & 3600 \\
Gualeguaychú & 1780 & 2000 \\
Gualeguay & 1780 & 1600 \\
La Bajada & 1730 & 3000 \\
Nogoyá & 1793 & 1500 \\
Coronda & 1768 & 2000 \\
Rosario & 1730 & 3500
\end{tabular}

La estimación de Félix de Azara se acerca a la cifra que dan los Betlemitas en 1794 al intentar establecer un hospital en Santa Fe (de 4 a 5000 almas) y a la que ofrece el Procurador Larramendi en su informe de 1795, "computando las gentes de todas las calidades y estados" ${ }^{87}$. En 1801, D. Pedro Tuella, vecino de Rosario, publicó en El Telégrafo Mercantil de Buenos Aires, Tomo III, una "Relación Histórica del pueblo y jurisdicción del Rosario de Los Arroyos", en el que le atribuye un total de 5879 almas, 80 casas y ranchos y más de 84 estancias prósperas en las 20 leguas cuadradas de su jurisdicción. Es llamativo que en sólo cuatro años, la población haya aumentado tanto, aún considerando la llegada de inmigrantes.

87 Cervera, Manuel: Historia de la ciudad y provincia de Santa Fe, T. 1, págs. 669-671 y Apéndice. 